\title{
Analysis of pollen loads in a wild bee community (Hymenoptera: Apidae) - a method for elucidating habitat use and foraging distances*
}

\author{
Marion BeIL ${ }^{1}$, Helmut HorN ${ }^{2}$, Angelika SchWABE ${ }^{1}$ \\ ${ }^{1}$ Darmstadt University of Technology, Dept. Biology (Geobotany/Vegetation Ecology), Schnittspahnstr. 4, \\ 64287 Darmstadt, Germany \\ ${ }^{2}$ University of Hohenheim, Landesanstalt für Bienenkunde, August-von-Hartmann-Str. 13, \\ 70599 Stuttgart, Germany
}

Received 20 November 2007 - Revised 28 February 2008 - Accepted 18 March 2008

\begin{abstract}
Resource utilisation and foraging ranges of Apidae (excluding Apis and Bombus) were studied in sandy grasslands of the temperate zone by pollen analysis combined with direct observation of bees. Planttaxa composition of 558 pollen loads collected from 56 bee species was determined. We recorded flowervisits using plot-based observations and resource utilisation using pollen analysis. For the most important entomophilous plant species flower-visitation and pollen-analytical data correspond (e.g. Berteroa incana, Centaurea stoebe, Potentilla argentea). Whenever pollen of plant species that are limited in their occurrence could be detected, we were able to use pollen analysis to determine foraging distances, but not maximum foraging distances. Using tree pollen, minimum flight ranges up to $1250 \mathrm{~m}$ were documented even for bees with $7 \mathrm{~mm}$ body size. Thus pollen analysis not only provides valuable information about foraging on different spatial scales, but also enables foraging ranges to be calculated without experimental manipulation.
\end{abstract}

flight range / foraging range / spatial scales / pollen analysis / floral resources

\section{INTRODUCTION}

Apidae are pollinators of many wild and cultivated plant species and as such play an important role in the conservation of plant species and whole ecosystems (Corbet et al., 1991; Kevan, 1999; Kratochwil, 2003; Klein et al., 2007; Kremen et al., 2007). With the exception of Bombus (e.g. Osborne et al., 1999; Walther-Hellwig and Frankl, 2000; Kreyer et al., 2004; Carvell et al., 2004; Goulson et al., 2005; Pywell et al., 2005, Westphal et al., 2006a, b) very little is yet known about resource utilisation and foraging ranges of wild bee species in ecosystems (Westrich, 1996; Greenleaf et al., 2007).

Corresponding author: A. Schwabe, schwabe@bio.tu-darmstadt.de

* Manuscript editor: Stan Schneider
To extend this knowledge we used two different methods to study resource utilisation by wild bee species: the first was plot-based observation of bees and their flower resources, and secondly we analysed pollen loads of the observed bee individuals. Then we asked whether the analysed loads contained pollen types which are very limited in their occurrence in the field. This would enable us to determine minimum flight ranges of wild bees without experimental manipulation. We excluded Bombus from our studies, because a great deal of data concerning resource utilisation and flight ranges of bumblebees already exists.

Some previous studies have used the observation method (observation or capture of bee individuals on a defined flower resource in the field) on the level of bee communities and floral resources to determine the supposed 
resource utilisation (e.g. Kratochwil, 1984; Minckley et al., 1999; Steffan-Dewenter and Tscharntke, 2001). Analysis of bee pollenloads documents the used resources and has so far been applied in only a few studies (Westrich and Schmidt, 1986, 1987; Kohl, 1988, 1989; Carvell et al., 2006); when used it often refers to only one wild bee species (Quiroz-Garcia et al., 2001; Williams and Tepedino, 2003; Kraemer and Favi, 2005) or Apis mellifera L. (Diaz-Losada et al., 1998; De-Sá-Otero et al., 2005).

Various approaches have been employed to determine foraging ranges of wild bees, mostly connected with experimental manipulation. One method (harmonic radar) is only suitable for larger species (e.g. Bombus). Artificial displacements from the nests were used to measure the maximal foraging distances of some bee species (Wesserling, 1996; Goulson and Stout, 2001; Gathmann and Tscharntke, 2002). Another method is to employ feedertraining-techniques, in which artificial feeders are moved progressively further away from the nest (Greenleaf et al., 2007). To estimate foraging distances for selected bee species (but not maxima), mark-recapture techniques were used but mostly with small numbers of recaptured bees (Greenleaf et al., 2007). Furthermore, pollen mapping was applied (pollen taken from the nest is identified and floral resources in the surrounding area are mapped to calculate the minimum foraging distance); reviewed by Greenleaf et al. (2007).

Concerning social bees, genetic methods have also been used to analyse their foraging ranges. The method is based on the determination of sisters, which are foraging from the same nest (Knight et al., 2005; Greenleaf et al., 2007).

We have chosen threatened open sand ecosystems in the temperate zone as model system for our approach to study resource utilization by wild bee species. The sandy grassland is characterized by a great diversity of pollen resources, and the open habitats include numerous nest-sites of ground-nesting bee species. The investigated sites are severely threatened NATURA 2000-areas (a system of protected areas with high conservation status in the European Union, see, e.g., Müssner and Plachter, 2002).

Inland sand ecosystems are among the most endangered habitats in Central Europe, and knowledge about the endangered wild bees, their floral resources and foraging ranges is essential for their protection and management.

The aim of the present study was to analyse the pollen loads of wild bees in sand ecosystems in order to answer the following questions: Which pollen types are detectable on bees in pollen loads? What are the advantages of combining data obtained by direct observations of bee foraging and by the analysis of pollen loads? Is pollen analysis suitable for elucidating resource use by bees on different spatial scales and for determining foraging distances of wild bees?

\section{MATERIALS AND METHODS}

\subsection{Study area}

All study sites were located in the northern upper Rhine valley near Darmstadt (Germany). The studies were carried out in the following open sandy habitats near Darmstadt, which are listed as nature protection areas and "Fauna-Flora-Habitat" areas of the European Union: "Ehemaliger AugustEuler-Flugplatz von Darmstadt" (= AEF; $8^{\circ} 35^{\prime} \mathrm{E}$, $\left.49^{\circ} 51^{\prime} \mathrm{N}\right)$, "Griesheimer Düne und Eichwäldchen" (= GD; $8^{\circ} 34^{\prime}$ E, 49 $50^{\circ} \mathrm{N}$ ), "Rotböhl" (Weiterstadt; $8^{\circ} 37^{\prime} \mathrm{E}, 49^{\circ} 56^{\prime} \mathrm{N}$ ); additionally we studied two isolated sandy grassland areas near Griesheim $\left(8^{\circ} 35^{\prime} \mathrm{E}, 49^{\circ} 51^{\prime} \mathrm{N}\right.$ and $8^{\circ} 35^{\prime} \mathrm{E}$, $49^{\circ} 50^{\prime} \mathrm{N}$ ), embedded in an intensively managed agricultural landscape with large amounts of asparagus and strawberry-fields and mostly scattered woody species. The vegetation is characterized by an endangered complex of habitats of Corynephoretalia, Allio-Stipetum and Armerio-Festucetum trachyphyllae and additionally slightly ruderalized sites. Ruderal sites are defined by disturbed conditions, resulting from human activity (e.g., former fields). The local climate is characterized by a mean annual temperature of $9-10{ }^{\circ} \mathrm{C}$ and a mean annual precipitation rate of about $700 \mathrm{~mm}$ (Walter and Lieth, 1967). 


\subsection{Direct observations: Recording of wild bees and floral resources}

A grid system was established throughout the whole investigation area with circular grid points of mainly $65 \mathrm{~m}$ distance from the center of the points. Apidae and their flower resources present at every grid point $(n=63)$ within a radius of $8 \mathrm{~m}$ were recorded. The grid points were distributed with equal density in all site types (normally 9 grid points for each type, in two cases of very small isolated areas only 3 to 6 ).

The bee surveys were carried out for the years 2004 and 2005 once or twice per week in dryweather periods with minimum temperatures higher than $12{ }^{\circ} \mathrm{C}$ from April to September $(15$ minutes for each grid point). Some bee species could be identified in the field (Dasypoda hirtipes, Andrena carbonaria agg.); they were recorded and - if pollen loads were present - they were netted and pollen loads collected. All other bees were caught with a hand net directly on their flower resources and, if necessary, frozen for later identification. For the combined data obtained by observation and pollen analysis, we included only the data for bee species having individuals with pollen loads.

The following data were recorded for all collected and observed bee individuals: species, date, flower resource, grid point. Characteristic beespecies of sand habitats (target species, sensu Bakker and Berendse, 1999) were defined according to various sources (Westrich, 1990; Saure, 1992; Krüss, 1994; Schmid-Egger et al., 1995). Nomenclature follows Westrich (1990), whereas for identification we used different keys (Scheuchl, 1995, 1996; Mauss, 1996; Scheuchl and Schmid-Egger, 1997; Amiet et al., 1999, 2001).

\subsection{Pollen analysis: Pollen collection and determination}

We were able to collect and analyze 558 pollen loads (from 1574 individuals observed) from 56 bee species. Altogether 288 loads were collected from "AEF" and "GD", whereas 187 pollen loads were collected at "Rotböhl" and 83 at two fragmented areas near Griesheim. Pollen loads were removed carefully with insect pins (for detailed method information see Westrich and Schmidt, 1986).

For homogenisation all pollen samples were dissolved in water, put on object slides and embedded in glycerine jelly. A second preparation of every sample was produced with fuchsin staining glycerine jelly to increase contrasts. For identification purposes a pollen herbarium was installed as a reference collection to document all entomophilous plant species present at our study sites. Flowers from these plants were placed on watch glasses and covered with diethyl ether to remove the grease from the pollen. After the diethyl ether evaporated, the remaining pollen grains were embedded in glycerine jelly with and without fuchsin (method used in the "Landesanstalt für Bienenkunde", University of Hohenheim, Germany).

Pollen samples were analysed using a light microscope, and identified with reference to the literature (Zander, 1935; Moore and Webb, 1978; Sawyer, 1981) and the prepared pollen herbarium. According to the cited references determination is not possible for some pollen types; therefore these types were pooled to higher level taxa (e.g., Medicago-type includes Medicago minima and Medicago falcata; Senecio-type comprises Senecio jacobaea, Senecio vernalis and $\mathrm{He}$ lichrysum arenarium). Cerastium arvense and Vicia angustifolia were included in the Caryophyllaceaegroup or Vicia-type, respectively. We made exceptions if there was only one species of a certain pollen type flowering in the whole investigation area and surroundings without any phenological overlap (for example Hieracium pilosella, belonging to the Taraxacum-type together, e.g., with Crepis capillaris and Hypochaeris radicata). In this case we assigned the pollen to Hieracium pilosella. The species composition of all pollen loads and the amount of the pollen types in the bulk sample were estimated in percentages; those species accounting for less than $1 \%$ were excluded from further analysis because they may be contaminations (Westrich and Schmidt, 1986). By collecting each pollen sample separately in the field in clean glasses, we excluded contamination as much as possible. The absolute amount of a pollen load was not considered in the analysis.

\subsection{Foraging ranges}

To calculate the minimal foraging ranges of Apidae for a specific resource, the pollen of plant species with restricted local occurrence at some distance from the plot areas was used, if present in the pollen loads (Tilia sp., Gleditsia triacanthos, Aesculus hippocastaneum, Fragaria vesca/cultivar). The distance between the observation plot where the bee was observed and the nearest individual plant reflects the minimum linear distance. 


\section{RESULTS}

\subsection{Observation and pollen records: floral resources}

By direct observation within the grid system we detected a total of 35 flowering plant species which were visited by Apidae (excluding Apis and Bombus) (Tab. I). The species composition is typical for the abovementioned sand vegetation complex, but ruderal species (r) occurred. The most abundant species were: Berteroa incana (r), Centaurea stoebe, Crepis capillaris, Hieracium pilosella, Sisymbrium altissimum (r) and Potentilla argentea. Pollen analysis differentiated 61 pollen types. The most abundant species determined by pollen load analysis were: Berteroa incana, Centaurea stoebe, Crepis capillaris, Hieracium pilosella (partly assigned to Taraxacum-type), Potentilla argentea and Sisymbrium altissimum.

The use of different plant species growing outside of the grid system was documented by pollen analysis; these are woody species (Acer pseudoplatanus, Aesculus hippocastaneum, Gleditsia triacanthos, Tilia sp., Prunoideae-and Pomoideae-type), and additionally species of the agricultural landscape (Centaurea cyanus, Fragaria probably cultivar, Phacelia tanacetifolia, Mustard-group, Rape-group).

\subsection{Foraging of bee species}

With the exception of three bee species the majority of the analysed bee species showed a broader use of floral resources, surpassing the resources of the restricted habitat-specific plot approach (Tab. II). Two of the three species with narrow use of floral resources are polylectic, but with known preference for Fabaceae (Andrena ovatula) or Asteraceae (Lasioglossum villosulum). Colletes fodiens is an oligolectic species feeding on Asteraceae (Westrich, 1990). The mean number of pollen types per pollen sample ranged from $1.0(\mathrm{La}-$ sioglossum pauxillum, Lasioglossum villosulum) to 3.1 (Andrena flavipes). The detailed results of bee species' resource utilisation are shown in Table III. In spite of the broader use of different resources, the quantities of plant-specific pollen were considerable. E.g., individuals of Andrena carbonaria agg. (Andrena pilipes group, see Schmid-Egger and Patiny, 1997) which were detected on flowers of Sisymbrium altissimum collected this pollen intensively $(20-21 \%$ of the loads contained 91-100\% Sisymbrium pollen). In the case of the 27 individuals of Andrena carbonaria agg. observed on inflorescences of Centaurea stoebe, more than half of the pollen samples contained up to $60 \%$ Centaurea pollen.

\subsection{Foraging ranges of bee species}

Two pollen samples derived from $\mathrm{La}$ sioglossum calceatum contained pollen from Aesculus hippocastaneum (one individual with $20 \%$ of the sample), although the nearest occurrence of Aesculus is found outside the studied sandy grassland area, at a minimum distance of between $700 \mathrm{~m}$ and $1000 \mathrm{~m}$ from the plot areas (Tab. IV). Two individuals of $L a$ sioglossum calceatum whose pollen loads contained Fragaria probably cultivar were found in the western area of the nature reserve "AEF"; Fragaria vesca is absent in this area, and the strawberry fields are located at a distance of $130-350 \mathrm{~m}$, separated by a $275-\mathrm{m}$ stripe of a 6- to 7-m-tall Pinus sylvestris plantation. Altogether four bees were detected with pollen of Tilia sp.: Andrena carbonaria agg., Andrena flavipes, Andrena dorsata and Lasioglossum fulvicorne, occuring between 600 and $1250 \mathrm{~m}$ away from the study plots, which indicates that these bee species foraged a minimum distance of $600 \mathrm{~m}$ for this particular resource (Tab. IV). Two pollen loads from Andrena flavipes, visiting Crepis capillaris at a fragmented site, contained high percentages of Gleditsia triacanthos, which was growing at a distance of about $625 \mathrm{~m}$. Figure 1 shows detected minimal foraging ranges for specific floral resources of some bee species; three species with different body sizes had minimum flight ranges surpassing $1100 \mathrm{~m}$ (Andrena carbonaria agg., Andrena flavipes, Lasioglossum fulvicorne), whereas the detected distance for Lasioglossum calceatum reaches at least $1000 \mathrm{~m}$ and for Andrena dorsata $650 \mathrm{~m}$. All mentioned bee species are groundnesting. 
Table I. Resource utilisation by wild bees: comparison of observation method and pollen analysis (558 pollen samples). $*$ = Characteristic plant species (target species) of sand ecosystems. Pollen type: classification of pollen types, if species-based determination was not possible (e.g., in case of phenological overlap). Observation method: percent of flowers on which bees were observed. Pollen analysis: mean percent \pm SE of pollen type per pollen sample, collected from netted bee.

\begin{tabular}{|c|c|c|c|}
\hline Pollen resource & Pollen type & Observation method & Pollen analysis \\
\hline Acer pseudoplatanus & & 0 & $0.07 \pm 0.07$ \\
\hline Achillea-type & & 0 & $0.29 \pm 0.19$ \\
\hline Aesculus hippocastaneum & & 0 & $0.04 \pm 0.04$ \\
\hline Allium sp. & & 0 & $0.02 \pm 0.02$ \\
\hline Alyssum alyssoides* & & 0.18 & 0 \\
\hline Armeria maritima* & & 0.18 & $0.18 \pm 0.18$ \\
\hline Asparagus sp. & & 0 & $0.25 \pm 0.19$ \\
\hline Berteroa incana* & & 19 & $19.11 \pm 1.51$ \\
\hline Campanula rapunculus* & & 2 & $1.60 \pm 0.51$ \\
\hline Carduus nutans* & & 2 & $1.46 \pm 0.48$ \\
\hline Caryophyllaceae-group & & 0 & $1.44 \pm 0.37$ \\
\hline Centaurea cyanus & & 0 & $0.07 \pm 0.07$ \\
\hline Centaurea stoebe* & & 13 & $9.10 \pm 1.08$ \\
\hline Cerastium arvense* & Caryophyllaceae-group & 1 & 0 \\
\hline Chenopodiaceae* & & 0 & $0.04 \pm 0.04$ \\
\hline Convolvulus arvensis* & & 0.18 & $0.01 \pm 0.01$ \\
\hline Coronilla varia & & 0 & $0.09 \pm 0.06$ \\
\hline Crepis capillaris* & Taraxacum-type & 12 & $5.65 \pm 0.96$ \\
\hline Dianthus carthusianorum $*$ & & 0.18 & 0 \\
\hline Echium vulgare* & & 1 & $0.56 \pm 0.25$ \\
\hline Erodium cicutarium $*$ & & 1 & $0.85 \pm 0.29$ \\
\hline Euphorbia cyparissias* & & 1 & $0.74 \pm 0.30$ \\
\hline Fragaria vesca & & 0 & $0.09 \pm 0.09$ \\
\hline Geranium molle* & & 1 & $0.66 \pm 0.32$ \\
\hline Gleditsia triacanthos & & 0 & $0.17 \pm 0.12$ \\
\hline Heliantheтит nummularium* & & 0 & $0.07 \pm 0.06$ \\
\hline Helichrysum arenarium $*$ & & 2 & $2.32 \pm 0.64$ \\
\hline Hieracium pilosella* & Taraxacum-type & 11 & $9.48 \pm 1.23$ \\
\hline Hypericum perforatum* & & 0 & $0.31 \pm 0.18$ \\
\hline Hypochaeris radicata* & Taraxacum-type & 4 & $0.73 \pm 0.36$ \\
\hline Jasione montana* & & 0.36 & $0.25 \pm 0.19$ \\
\hline Legume-type & & 0 & $0.04 \pm 0.04$ \\
\hline Malva alcea* & & 1 & $0.72 \pm 0.36$ \\
\hline Medicago-type & & 0 & $0.60 \pm 0.27$ \\
\hline Medicago falcata* & Medicago-type & 4 & $3.85 \pm 0.78$ \\
\hline Medicago minima* & Medicago-type & 1 & $0.19 \pm 0.18$ \\
\hline
\end{tabular}


Table I. Continued.

\begin{tabular}{|c|c|c|c|}
\hline Pollen resource & Pollen type & Observation method & Pollen analysis \\
\hline Mustard-group & & 0 & $0.32 \pm 0.15$ \\
\hline Oenothera biennis* & & 0.18 & $0.004 \pm 0.003$ \\
\hline Ononis repens* & & 3 & $3.37 \pm 0.68$ \\
\hline Phacelia tanacetifolia & & 0 & $0.04 \pm 0.04$ \\
\hline Polygonaceae & & 0 & $0.17 \pm 0.17$ \\
\hline Pomoideae-type & & 0 & $0.13 \pm 0.08$ \\
\hline Potentilla-type & & 0 & $0.14 \pm 0.14$ \\
\hline Potentilla argentea* & & 5 & $4.57 \pm 0.82$ \\
\hline Potentilla tabernaemontan ${ }^{*}$ & & 1 & $0.54 \pm 0.28$ \\
\hline Prunoideae-type & & 0 & $0.13 \pm 0.11$ \\
\hline Rape-group & & 0 & $3.61 \pm 0.59$ \\
\hline Robinia pseudoacacia & & 0 & $0.002 \pm 0.002$ \\
\hline Rubus-type & & 0 & $0.36 \pm 0.15$ \\
\hline Rumex sp. & & 0 & $0.37 \pm 0.19$ \\
\hline Sedum acre* & & 1 & $0.43 \pm 0.26$ \\
\hline Senecio jacobaea* & Senecio-type & 1 & $0.71 \pm 0.30$ \\
\hline Senecio vernalis* & Senecio-type & 2 & $1.83 \pm 0.51$ \\
\hline Senecio-type & & 0 & $0.38 \pm 0.15$ \\
\hline Silene conica* & & 0.36 & $0.18 \pm 0.18$ \\
\hline Sisymbrium altissimum* & Mustard-group & 8 & $7.14 \pm 1.07$ \\
\hline Taraxacum-type & & 0 & $10.82 \pm 1.24$ \\
\hline Thistle-type & & 0 & $0.25 \pm 0.17$ \\
\hline Tilia sp. & & 0 & $0.61 \pm 0.25$ \\
\hline Tragopogon dubius* & & 0.18 & 0 \\
\hline Trifolium arvense* & Trifolium sp. & 1.08 & $0.54 \pm 0.31$ \\
\hline Trifolium sp. & & 0 & $0.60 \pm 0.26$ \\
\hline Verbascum phlomoides* & & 0.18 & $0.18 \pm 0.18$ \\
\hline Vicia angustifolia* & & 0.36 & 0 \\
\hline Vicia villosa* & & 1 & $1.40 \pm 0.49$ \\
\hline Vicia-type & & 0 & $0.22 \pm 0.18$ \\
\hline
\end{tabular}

\section{DISCUSSION}

\subsection{Observation and pollen records: floral resources}

Observations allowed the documentation of bee visitation of defined floral resources in threatened sand ecosystems. The most exploited foraged plant species are those frequently present in the sand vegetation, partly even ruderal species (Berteroa, Sisymbrium) and in no case threatened plant species (Beil, 2007). Conversely, these common plant 
Table II. Results of observations and pollen analysis for all wild bee species for which at least 6 pollen samples were collected. $*=$ Characteristic bee species (target species) of sand ecosystems. SE $=$ standard error.

\begin{tabular}{|c|c|c|c|c|}
\hline Bee species & $\begin{array}{l}\text { Pollen } \\
\text { samples }\end{array}$ & $\begin{array}{l}\text { Number of } \\
\text { visited flower } \\
\text { resources } \\
\text { (observation } \\
\text { method) }\end{array}$ & $\begin{array}{l}\text { Number of } \\
\text { pollen types } \\
\text { (pollen analysis) }\end{array}$ & $\begin{array}{l}\text { Mean number } \\
\text { of pollen types } \\
\text { per pollen load } \\
\pm \mathrm{SE}\end{array}$ \\
\hline Andrena carbonaria agg.* & 83 & 4 & 15 & $1.8 \pm 0.1$ \\
\hline Lasioglossum leucozonium (Schrank, 1781) & 52 & 11 & 17 & $1.5 \pm 0.1$ \\
\hline Andrena flavipes Panzer, 1799 & 49 & 10 & 24 & $3.1 \pm 0.2$ \\
\hline Lasioglossum pauxillum (Schenck, 1853) & 35 & 3 & 2 & $1.0 \pm 0.0$ \\
\hline Halictus leucaheneus* Ebmer, 1972 & 30 & 6 & 16 & $2.0 \pm 0.1$ \\
\hline Lasioglossum calceatum (Scopoli, 1763) & 30 & 11 & 22 & $2.0 \pm 0.2$ \\
\hline Dasypoda hirtipes* (Fabricius, 1793) & 26 & 3 & 4 & $1.3 \pm 0.1$ \\
\hline Andrena dorsata (Kirby, 1802) & 21 & 1 & 16 & $2.0 \pm 0.2$ \\
\hline Halictus sexcinctus (Fabricius, 1775) & 21 & 4 & 12 & $2.1 \pm 0.2$ \\
\hline Andrena ovatula (Kirby, 1802) & 20 & 6 & 5 & $1.3 \pm 0.1$ \\
\hline Halictus smaragdulus Vachal, 1895 & 16 & 9 & 17 & $2.2 \pm 0.2$ \\
\hline Lasioglossum albipes (Fabricius, 1781) & 16 & 6 & 13 & $1.9 \pm 0.3$ \\
\hline Melitta leporina Panzer, 1799 & 15 & 3 & 5 & $1.4 \pm 0.1$ \\
\hline Andrena bimaculata* $($ Kirby, 1802) & 12 & 2 & 5 & $1.7 \pm 0.2$ \\
\hline Megachile maritima* (Kirby, 1802) & 11 & 4 & 10 & $2.1 \pm 0.3$ \\
\hline Halictus subauratus (Rossi, 1792) & 8 & 5 & 12 & $2.5 \pm 0.3$ \\
\hline Colletes fodiens $*$ (Fourcroy, 1785) & 7 & 2 & 2 & $1.3 \pm 0.2$ \\
\hline Halictus confusus* Smith, 1853 & 7 & 3 & 7 & $1.7 \pm 0.3$ \\
\hline Lasioglossum villosulum (Kirby, 1802) & 7 & 1 & 1 & $1.0 \pm 0.0$ \\
\hline Colletes similis Schenck, 1853 & 6 & 1 & 2 & $1.2 \pm 0.2$ \\
\hline Lasioglossum fulvicorne (Kirby, 1802) & 6 & 5 & 8 & $1.5 \pm 0.3$ \\
\hline Lasioglossum morio (Fabricius, 1793) & 6 & 5 & 7 & $2.0 \pm 0.3$ \\
\hline
\end{tabular}

species were visited by several threatened bee species (e.g. Andrena carbonaria agg. Halictus leucaheneus, Dasypoda hirtipes). In general, by means of the observation method specific flower visits could be depicted well and with a high degree of completeness on the plot level.

Pollen analysis offers two advantages compared to the observation method. Firstly, pollen analysis revealed the actual use of pollen resources and excluded nectar-only collection and other bee activities that were included in observation of bee visits. Sipes and Tepedino (2005) pointed out that bees visit a relatively large number of plant species because of their nectar rather than pollen production (e.g., in our case, probably $D i$ anthus carthusianorum). Secondly, results of pollen analysis demonstrate that the bee visits were not limited to typical plant species of sand ecosystems but that they also utilise resources in the surrounding agricultural landscape. Even characteristic species ("target species") of open sand habitats (e.g. Andrena carbonaria agg.) use the pollen of flowering trees.

Disadvantages of the pollen analytical approach are as follows: firstly, not all bee individuals carry pollen loads (in our case we observed 1574 individuals and were able to extract 558 pollen loads); secondly, often a species-based determination is not possible by 
Table III. Pollen percent of total pollen load of the respective plant species, which was visited by different bee species ( $\mathrm{n}>10$ individuals per plant species).

\begin{tabular}{llcccccc}
\hline Bee species & Netted on & \multicolumn{5}{c}{ Percent of total pollen load } \\
\cline { 2 - 7 } & & $\mathrm{n}$ & $1-30$ & $31-60$ & $61-80$ & $81-90$ & $91-100$ \\
\hline Andrena carbonaria agg. & Berteroa incana & 33 & 0 & 5 & 2 & 6 & 20 \\
& Centaurea stoebe & 27 & 10 & 5 & 1 & 3 & 8 \\
& Sisymbrium altissimum & 21 & - & 1 & - & - & 20 \\
Andrena dorsata & Berteroa incana & 20 & 1 & 5 & 3 & 1 & 10 \\
Andrena flavipes & Berteroa incana & 20 & 1 & 3 & 7 & 2 & 7 \\
& Centaurea stoebe & 12 & 3 & 2 & 1 & 3 & 3 \\
Dasypoda hirtipes & Crepis capillaris & 22 & - & - & - & 1 & 21 \\
Halictus leucaheneus & Potentilla argentea & 12 & - & 2 & - & 1 & 9 \\
Lasioglossum calceatum & Berteroa incana & 11 & 2 & 2 & 1 & - & 6 \\
Lasioglossum leucozonium & Crepis capillaris & 12 & 2 & 1 & 1 & - & 8 \\
& Hypochaeris radicata & 12 & 2 & - & - & - & 10 \\
Lasioglossum pauxillum & Hieracium pilosella & 15 & - & 1 & - & 1 & 13 \\
Melitta leporina & Hieracium pilosella & 29 & - & - & - & - & 29 \\
\hline
\end{tabular}

Table IV. "Rare" pollen types of plant species that only occur in the vicinity of designated study sites. Frag = Fragmented site, AEF = Study site "Euler-Flugplatz"; Date = date on which bee was collected; [\%] $=$ percent of total pollen load.

\begin{tabular}{|c|c|c|c|c|c|c|}
\hline Bee species & Locality & Distance $[\mathrm{m}]$ & Date & Netted on & "Rare" pollen & [\%] \\
\hline Lasioglossum calceatum & $\mathrm{AEF}$ & 700 & 02.05 .05 & Cerastium arvense & Aesculus hippocastaneum & 20 \\
\hline Lasioglossum calceatum & $\mathrm{AEF}$ & 1000 & 04.05 .04 & Erodium cicutarium & Aesculus hippocastaneum & 1 \\
\hline Andrena flavipes & Frag & 625 & 30.07 .04 & Crepis capillaris & Gleditsia triacanthos & 35 \\
\hline Andrena flavipes & Frag & 625 & 30.07 .04 & Crepis capillaris & Gleditsia triacanthos & 60 \\
\hline Lasioglossum calceatum & $\mathrm{AEF}$ & 130 & 16.05 .04 & Erodium cicutarium & Fragaria vesca/cultivar & 50 \\
\hline Lasioglossum calceatum & $\mathrm{AEF}$ & 350 & 04.05 .04 & Erodium cicutarium & Fragaria vesca/cultivar & 1 \\
\hline Andrena dorsata & $\mathrm{AEF}$ & 650 & 05.07 .04 & Berteroa incana & Tilia sp. & 50 \\
\hline Lasioglossum fulvicorne & $\mathrm{AEF}$ & 1250 & 06.07 .04 & Campanula rapunculus & Tilia sp. & 5 \\
\hline Andrena carbonaria agg. & $\mathrm{AEF}$ & 1250 & 06.07 .04 & Berteroa incana & Tilia sp. & 3 \\
\hline Andrena flavipes & $\mathrm{AEF}$ & 1150 & 06.07 .04 & Berteroa incana & Tilia sp. & 1 \\
\hline
\end{tabular}

means of pollen analysis. Some of these critical taxa can only be identified on species level, if there is sufficient knowledge about the plant species and flower phenology of the study area and surroundings and there is no phenological overlap of certain pollen types.

It is remarkable that the main pollen resources of wild bees were detected well with both pollen analysis and observation methods. Both methods revealed bee visitation of the same top six plant species with a

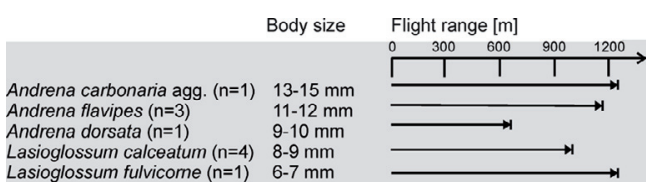

Figure 1. Minimal flight ranges of bee species (calculated by occurrence of locally restricted plant species in pollen samples).

slight difference in the sequence. Pollen analysis is more time-consuming than observation 
methods, but gives additional results about the foraging behaviour of bee species in detail (proof that pollen has been collected) and information about the use of sites outside the plot-based study area (see also Carvell et al., 2006).

\subsection{Foraging behaviour of bee species}

For many bee species high absolute values of specific pollen types were recorded in their pollen loads. This leads to the conclusion that although species use a broad spectrum of pollen resources, they may visit only a few plant species during one foraging trip. Halictus subauratus and Andrena flavipes turned out to be the species with the highest values of mixed pollen loads. In accordance with the activity during a long season (for example social species like Lasioglossum calceatum and Lasioglossum pauxillum), these species used a broad taxonomic spectrum of pollen resources. Michener (2007) stated that "a long season of activity must usually be associated with dependence on a diversity of flowers".

According to our results the main foraging areas of the investigated bee species are sand ecosystems; only low percentages were found to forage in the surrounding agricultural landscape (e.g., in the case of Fragaria: we determined $50 \%$ pollen in one pollen load, further we detected Prunoideae-and Pomoideae-type, Phacelia tanacetifolia, Mustard-group, Rapegroup).

\subsection{Foraging ranges of bee species}

Ricketts et al. (2006) stated in a review article: "Following tiny and fast-flying insects over distances more than a few meters has proven a substantial challenge to which we have not yet discovered a reliable solution". Information on foraging ranges of wild bees with small body size is still rare (Greenleaf et al., 2007). There are indications that their dispersal capacity is limited (Artz and Waddington, 2006; Dupont and Nielsen, 2006). Foraging ranges should be positively correlated with body size (Gathmann and Tscharntke, 2002; Beil, 2007; Greenleaf et al.,
2007). Gathmann and Tscharntke (2002) demonstrated foraging ranges of 150-600 m between nest-sites and foraging resources, by means of translocation experiments.

According to a predictive model based on body size, elaborated by Greenleaf et al. (2007), small Lasioglossum species ( $L$. malachurum, L. pauxillum) should have only maximum foraging distances of 220 or $600 \mathrm{~m}$, respectively. Probably there are barrier effects for small bee species caused by different elements of the landscape matrix such as forest stripes (Ricketts, 2001; Ricketts et al., 2006); for bumblebees often barrier effects of forests are not provable (Kreyer et al., 2004).

In our approach we used an indirect path to determine minimum ranges for foraging trips. As already mentioned, we recorded pollen loads containing plant species which are not present in the plot sites (e.g. Aesculus hippocastaneum, Tilia sp., Gleditsia triacanthos, Phacelia tanacetifolia and Fragaria vesca/cultivar).

As regards our results, the foraging range up to $1000 \mathrm{~m}$ of the tiny L. calceatum is considerable and surpasses the distances found by a predictive model (Greenleaf et al., 2007, see above), particularly in view of the potential barrier effect of a Pinus sylvestris-plantation. The bee species in which pollen of Tilia sp. was found are, with the exception of $\mathrm{La}$ sioglossum fulvicorne, larger species, which must have covered distances between 600 and $1250 \mathrm{~m}$. All bee species shown in Figure 1 are ground-nesting in the "AEF"-area. Some of the Halictinae species (in Fig. 1, L. calceatum) are primitively eusocial (Michener, 2007); it is not known whether the life style (social versus solitary life) of small bees affects their foraging range.

Our results show that pollen analysis is an appropriate method with which to analyse foraging ranges of even small Apidae, if - as in our case - observation data and pollen data complement each other. Therefore it is useful to employ both methods. The currently used methods such as harmonic radar (Carreck et al., 1999; Osborne et al., 1999) or recapture experiments with marked individuals (e.g. Walther-Hellwig and Frankl, 2000; Goulson and Stout, 2001; Westphal et al., 
2006b; Martin et al., 2006) are only suitable for bees with larger body size. Our results indicate that the range of small Apidae during their foraging trips can be larger than has previously been assumed. Pollen analysis is an important method for obtaining detailed knowledge of the whole spectrum of pollen resources, to document the potential of pollinators for agricultural use (see also Kraemer and Favi, 2005; Ricketts et al., 2006; Klein et al., 2007) as well as to elucidate the foraging ranges of wild bees, including small species.

\section{ACKNOWLEDGEMENTS}

The study was carried out with the support of a $\mathrm{PhD}$ grant to Marion Beil by the "Deutsche Bundesstiftung Umwelt" (Osnabrück) and a "Testing and Development Project" by the German Federal Agency for Nature Protection (BfN). We would like to thank the "Regierungspräsidium Darmstadt" and the "Landkreis Darmstadt-Dieburg" for permission to work in the nature protection areas and to collect bee individuals, H. Schwenninger (Stuttgart) and A. Schanowski (Bühl/Baden) for the examination of critical bee individuals and Prof. Dr. A. Kratochwil (Osnabrück) for helpful comments. The improvement of the English text by Dr. A. Thorson (Oxford) is appreciated. The manuscript benefited very much from the comments of two anonymous reviewers and the editor Stan Schneider.

Analyse des pelotes de pollen d'une communauté d'abeilles sauvages (Hymenoptera : Apidae) : une méthode permettant de mieux connaître l'utilisation de l'habitat et les distances de butinage.

Distance de vol / distance de butinage / échelle spatiale / analyse pollinique / ressource florale

Zusammenfassung - Analyse gesammelter Pollen in einer Wildbienen-Gemeinschaft (Hymenoptera: Apidae) - eine Methode zur besseren Kenntnis der Habitatnutzung und der zurückgelegten Entfernungen bei Sammelflügen. In bedrohten Binnenland-Sandökosystemen wurden die Ressourcennutzung und die Sammelflugdistanzen von Wildbienen (Apidae, ohne Apis und Bombus) mit Hilfe der Analyse von Pollenladungen und mit direkter Beobachtung untersucht. Das untersuchte Grasland auf Sandstandorten der temperaten Zone ist gekennzeichnet durch große Diversität von Pollenressourcen; diese offenen Lebensräume werden von einer Vielzahl vor allem endogäisch nistender Wildbienen genutzt.
558 Pollenladungen von 56 Bienenarten wurden auf ihre Zugehörigkeit zu Pflanzentaxa bestimmt. Mit Hilfe der Probeflächen-basierten Beobachtung von Blütenbesuchern konnten wir Besuche an 35 Habitat-typischen Pflanzenarten feststellen und zusätzlich mit Hilfe der Pollenanalyse die Nutzung weiterer Pollenressourcen aus dem Umland (insgesamt Nachweis von 61 Pollentypen). Die HauptPollenressourcen konnten mit beiden Methoden gut nachgewiesen werden. Sowohl bei der Pollenanalyse als auch bei der Beobachtung an Blüten waren die häufigsten sechs Pflanzenarten identisch, mit leichten Abweichungen in der quantitativen Reihung. Die Pollenanalyse ist zeitaufwändiger, aber ermöglicht die Gewinnung zusätzlicher Informationen zur Ressourcennutzung von Bienenindividuen auf höheren räumlichen Skalen. Aus botanischer Sicht sind die wichtigsten Nahrungsressourcen häufige Taxa der Sandflora. Es handelt sich um ruderale Arten (Berteroa, Sisymbrium) und allgemein nicht gefährdeten Pflanzenarten; viele blütenbesuchende Bienenarten sind jedoch in hohem Maße gefährdet (z.B. Andrena carbonaria agg. Halictus leucaheneus, Dasypoda hirtipes).

Es gibt immer noch geringe Kenntnisse zu den Sammelflugdistanzen, die Wildbienen zurücklegen können (mit Ausnahe von Apis und Bombus). Wenn Pollen von Pflanzenarten, die ein nur punktuelles lokales Vorkommen haben, feststellbar ist, können minimale Sammelflugdistanzen berechnet werden. Insbesondere durch den Nachweis von Gehölzpollen konnten wir auch für Bienenarten mit einer Körpergröße von nur $7 \mathrm{~mm}$ minimale Sammelflugdistanzen von bis zu 1250 m feststellen. Die Pollenanalyse ermöglicht nicht nur wertvolle Informationen zur Ressourcennutzung auf verschiedenen Skalenebenen, sondern es können auch minimale Sammelflugdistanzen ohne experimentelle Manipulation ermittelt werden. Unsere Ergebnisse weisen darauf hin, dass die bei Sammelflügen zurückgelegten Entfernungen auch bei Bienen mit kleiner Körpergröße größer sind als bisher angenommen.

Die Pollenanalyse ist eine wichtige Methode, um zum einen das gesamte taxonomische Spektrum der genutzten Pollenressourcen und das Potenzial der Bienenarten als Bestäuber in der Agrarlandschaft festzustellen und zum anderen die zurückgelegten Sammelflugdistanzen auch kleinerer Bienenarten zu ermitteln.

Fluggebiet / Nahrungsraum / räumliche Ebenen / Pollenanalyse / Blüten-Ressourcen

\section{REFERENCES}

Amiet F., Müller A., Neumeyer R. (1999) Fauna Helvetica - Apidae 2, CSCF und SEG, Neuchâtel.

Amiet F., Herrmann M., Müller A., Neumeyer R. (2001) Fauna Helvetica - Apidae 3, CSCF und SEG, Neuchâtel. 
Artz D.R., Waddington K.D. (2006) The effects of neighbouring tree islands on pollinator density and diversity, and on pollination of a wet prairie species, Asclepias lanceolata (Apocynaceae), J. Ecol. 94, 597-608.

Bakker J.P., Berendse F. (1999) Constraints in the restoration of ecological diversity in grassland and heathland communities, Trends Ecol. Evol. 14, 63-68

Beil M. (2007) Blütenbesuchende Wildbienengemeinschaften (Hymenoptera, Apoidea) in Sand-Ökosystemen, Dissertation, FB Biologie, TU Darmstadt.

Carreck N.L., Osborne J.L., Capaldi E.A., Riley J.R. (1999) Tracking bees with radar, Bee World 80, 124-131.

Carvell C., Meek W.R., Pywell R.F., Nowakowski M. (2004) The response of foraging bumblebees to successional change in newly created arable fields margins, Biol. Conserv. 118, 327-339.

Carvell C., Westrich P., Meek W.R., Pywell R.R., Nowakowski M. (2006) Assessing the value of annual and perennial forage mixtures for bumblebees by direct observation and pollen analysis, Apidologie 37, 326-340.

Corbet S.A., Williams I.H., Osborne J.L. (1991) Bees and the pollination of crops and wild flowers in the European Community, Bee World 72, 47-59.

De Sá-Otero M.P., Armesto-Baztán S., Diaz-Losada E. (2005) Initial data on the specific heterogeneity found in the bee pollen loads produced in the "Baixa Limia-Serra do Xurès" nature reserve, Acta Bot. Gallica 152, 361-375.

Diaz-Losada E., Ricciardelli-D’Albore G., Pilar SaaOtero M. (1998) The possible use of honeybee pollen loads in characterising vegetation, Grana 37, 155-163.

Dupont Y.L., Nielsen B.O. (2006) Species composition, feeding specificity and larval trophic level of flower-visiting insects in fragmented versus continuous heathlands in Denmark, Biol. Conserv. $131,475-485$.

Gathmann A., Tscharntke T. (2002) Foraging ranges of solitary bees, J. Anim. Ecol. 71, 757-764.

Goulson D., Stout J.C. (2001) Homing ability of the bumblebee Bombus terrestris (Hymenoptera: Apidae), Apidologie 32, 105-111.

Goulson D., Hanley M.E., Darvill B., Ellis J.S., Knight M.E. (2005) Causes of rarity in bumblebees, Biol. Conserv. 122, 1-8.

Greenleaf S.S., Williams N.M., Winfree R., Kremen C. (2007) Bee foraging ranges and their relationship to body size, Oecologia 153, 589-596.

Kevan P.G. (1999) Pollinators as bioindicators of the state of the environment: species, activity and diversity, Agr. Ecosyst. Environ. 74, 373-393.

Klein A.-M., Vaissière B.E., Cane J.H., SteffanDewenter I., Cunningham S.A., Kremen C., Tscharntke T. (2007) Importance of pollinators in changing landscapes for world crops, Proc. R. Soc. Lond. B 274, 303-313.

Knight M.E., Martin A.P., Bishop S., Osborne J.L., Hale R.J., Sanderson R.A., Goulson D. (2005) An interspecific comparison of foraging range and nest density of four bumblebee (Bombus) species, Mol. Ecol. 14, 1811-1820.

Kohl A. (1988) Der Corbicular-Pollen von Hummelarten (Bombus, Hymenoptera, Apidae) als Nachweis der im Jahreslauf besuchten Pflanzenarten und Phytozönosen, Dissertation Universität Freiburg, Fakultät für Biologie.

Kohl A. (1989) Untersuchungen von eingetragenem Pollen bei in künstlichen Nestern gehaltenen Hummelarten (Hymenoptera, Apoidea) und Rekonstruktion der besuchten Phytozönosen im Jahresverlauf, Verhandl. Ges. f. Ökol. (Göttingen 1987) 17, 713-718.

Kraemer M.E., Favi F.D. (2005) Flower phenology and pollen choice of Osmia lignaria (Hymenoptera: Megachilidae) in Central Virginia, Environ. Entomol. 34, 1593-1605.

Kratochwil A. (1984) Pflanzengesellschaften und Blütenbesucher-Gemeinschaften: Biozönologische Untersuchungen in einem nich mehr bewirtschafteten Halbtrockenrasen (Mesobrometum) im Kaiserstuhl (Südwestdeutschland), Phytocoenologia 11, 455-669.

Kratochwil A. (2003) Bees (Hymenoptera, Apidae) as keystone-species: specifics of resource and requisite utilisation in different habitat types, Ber. Reinh.-Tüxen-Ges. 15, 59-77.

Kremen C., Williams N.M., Aizen M.A., GemmillHerren B., LeBuhn G., Minckley R., Packer L., Potts S.G., Roulston T., Steffan-Dewenter I., Vázquez D.P., Winfree R., Adams L., Crone E.E., Greenleaf S.S., Keitt T.H., Klein A.-M., Regetz J., Ricketts T.H. (2007) Pollination and other ecosystem services produced by mobile organisms: a conceptual framework for the effects of land-use change, Ecol. Lett. 10, 299-314.

Kreyer D., Oed A., Walther-Hellwig K., Frankl R. (2004) Are forests potential landscape barriers for foraging bumblebees? Landscape scale experiments with Bombus terrestris agg. and Bombus pascuorum (Hymenoptera, Apidae), Biol. Conserv. 116, 111-118.

Krüss A. (1994) Die Stechimmen der Sandhausener Dünen, Beih. Veröff. Naturschutz Landschaftspflege Bad.-Württ. 80, 223-240.

Martin A.P., Carreck N.L., Swain J.L., Goulson D., Knight M.E., Hale R.J., Sanderson R.A., Osborne J.L. (2006) A modular system for trapping and mass-marking bumblebees: applications for studying food choice and foraging range, Apidologie $37,341-350$.

Mauss V. (1996) Bestimmungsschlüssel für die Hummeln der Bundesrepublik Deutschland, 6. Aufl., DJN, Hamburg. 
Michener C.D. (2007) The Bees of the World, 2nd ed., The Johns Hopkins University Press, Baltimore.

Minckley R., Cane J.H., Kervin L., Roulston T.H. (1999) Spatial predictability and resource specialization of bees (Hymenoptera: Apidae) at a superabundant, widespread resource, Biol. J. Linn. Soc. 67, 119-147.

Moore P.D., Webb J.A. (1978) An illustrated guide to pollen analysis, Hodder and Stoughton, London.

Müssner R., Plachter H. (2002) Methodological standards for nature conservation: case-study landscape planning, J. Nat. Conserv. 10, 3-23.

Osborne J.L., Clark S.J., Morris R.J., Williams I.H., Riley J.R., Smith A.D., Reynolds D.R., Edwards A.S. (1999) A landscape-scale study of bumble bee foraging range and constancy, using harmonic radar, J. Appl. Ecol. 36, 519-533.

Pywell R.F., Warman E.A., Carvell C., Sparks T.H., Dicks L.V., Bennett D., Wright A., Critchley C.N.R., Sherwood A. (2005) Providing foraging resources for bumblebees in intensively farmed landscapes, Biol. Conserv. 121, 479-494.

Quiroz-Garcia D.L., Martinez-Hernandez E., PalaciosChavez R., Galindo-Miranda N.E. (2001) Nest provisions and pollen foraging in three species of solitary bees (Hymenoptera: Apidae) from Jalisco, Mexico, J. Kans. Entomol. Soc. 74, 61-69.

Ricketts T.H. (2001) The matrix matters: effective isolation in fragmented landscapes, Am. Nat. 158, 87-99.

Ricketts T.H., Williams N.M., Mayfield M.M. (2006) Connectivity and ecosystem services: crop pollination in agricultural landscapes, in: Crooks K.R., Sanjayan M. (Eds.), Connectivity Conservation, Cambridge Univ. Press, New York, pp. 255-289.

Saure C. (1992) Die Stechimmenfauna der Binnendüne Baumberge in Berlin-Heiligensee im Vergleich mit anderen Trockengebieten in Berlin und Umgebung (Insecta: Hymenoptera Aculeata), Berl. Naturschutzblätter 36, 38-57.

Sawyer R. (1981) Pollen Identification for Beekeepers, University College Cardiff Press, Cardiff.

Scheuchl E. (1995) Illustrierte Bestimmungstabellen der Wildbienen Deutschlands und Österreichs, Bd. 1, Schlüssel der Gattungen und der Arten der Familie Anthophoridae, Eigenverlag, Velden.

Scheuchl E. (1996) Illustrierte Bestimmungstabellen der Wildbienen Deutschlands und Österreichs, Bd. 2, Schlüssel der Arten der Familien Megachilidae und Melittidae, Eigenverlag, Velden.

Scheuchl E., Schmid-Egger C. (1997) Illustrierte Bestimmungstabellen der Wildbienen Deutschlands und Österreichs unter der Berücksichtigung der Arten der Schweiz. - Bd. 3, Schlüssel der Arten der Familie Andrenidae, Eigenverlag, Velden.

Schmid-Egger C., Patini S. (1997) Anmerkungen zur Andrena-pilipes-Gruppe (= auct.), Bembix 8, 3742.
Schmid-Egger C., Risch S., Niehuis O. (1995) Die Wildbienen und Wespen in RheinlandPfalz (Hymenoptera, Aculeata). Verbreitung, Ökologie und Gefährdungssituation, Fauna Flora Rheinland-Pfalz, Beiheft 16.

Sipes S.D., Tepedino V.J. (2005) Pollen-host specificity and evolutionary patterns of host switching in a clade of specialist bees (Apidae: Diadasia), Biol. J. Linn. Soc. 86, 487-505.

Steffan-Dewenter I., Tscharntke T. (2001) Succession of bee communities on fallows, Ecography 24, 8393.

Walter H., Lieth H. (1967) Klimadiagramm-Weltatlas, VEB Gustav Fischer Verlag, Jena.

Walther-Hellwig K., Frankl R. (2000) Foraging habitats and foraging distances of bumblebees, Bombus spp. (Hym., Apidae), in an agricultural landscape, J. Appl. Entomol. 124, 299-306.

Wesserling J. (1996) Habitatwahl und Ausbreitungsverhalten von Stechimmen (Hymenoptera: Aculeata) in Sandgebieten unterschiedlicher Sukzessionsstadien, Dissertation, Cuvillier, Göttingen.

Westphal C., Steffan-Dewenter I., Tscharntke T. (2006a) Bumblebees experience landscapes at different spatial scales: possible implications for coexistence, Oecologia 149, 289-300.

Westphal C., Steffan-Dewenter I., Tscharntke T. (2006b) Foraging trip duration of bumblebees in relation to landscape-wide resource availability, Ecol. Entomol. 31, 389-394.

Westrich P. (1990) Die Wildbienen BadenWürttembergs, 2nd ed., Ulmer, Stuttgart.

Westrich P. (1996) Habitat requirements of central European bees and the problems of partial habitats, in: Matheson A., Buchmann S.L., O'Toole C., Westrich P., Williams I.H. (Eds.), The Conservation of Bees, Academic Press, London, pp. 1-16.

Westrich P., Schmidt K. (1986) Methoden und Anwendungsgebiete der Pollenanalyse bei Wildbienen (Hymenoptera, Apidae), Linzer Biol. Beitr. 18, 341-360.

Westrich P., Schmidt K. (1987) Pollenanalyse, ein Hilfsmittel beim Studium des Sammelverhaltens von Wildbienen (Hymenoptera, Apidae), Apidologie 18, 199-214.

Williams N.M., Tepedino V.J. (2003) Consistent mixing of near and distant resources in foraging bouts by the solitary mason bee Osmia lignaria, Behav. Ecol. 14, 141-149.

Zander E. (1935) Beiträge zur Herkunftsbestimmung bei Honig. I. Pollengestaltung und Herkunftsbestimmung bei Blütenhonig mit besonderer Berücksichtigung des deutschen Trachtgebietes, Verlag der Reichsfachgruppe Imker, Berlin. 